JUSTISI | 2019

\title{
Perbedaan Talak Satu, Dua dan Tiga Dalam Hukum Islam
}

\author{
Muhammad Asykur Muchtar \\ Fakultas Hukum Universitas Muhammadiyah Sorong \\ E-mail. : asykurs.hi@gmail.com
}

\begin{abstract}
Abstrak
Penilitian ini bertujuan untuk mengetahui perbedaan antara talak satu, dua dan tiga dalam hukum Islam. Serta untuk mengetahui tata cara serta aturan-aturan dalam menjatuhkan talak dalam hukum Islam.

Metode penelitian yang digunakan merupakan penelitian hukum normatif. Teknik pengumpulan data dilakukan dengan cara mengumpulkan data-data melalui buku-buku yang relevan dengan penelitian.

Hasil penelitian menunjukkan bahwa perbedaan talak satu, dua dan tiga adalah akibat yang ditimbulkannya. Pada talak satu dan dua suami masuh bisa merujuk istri tanpa harus mengucapkan akad yang baru dan dilakukan dalam masa iddah sang istri, sementara talak tiga suami tidak dapat rujuk kembali kepada istri sebelum sang istri menikah dengan laki-laki lain kemudian bercerai atau suami yang baru meninggal dunia. Sedangkan dalam menjatuhkan talak haruslah secara berurutan tidak boleh diucapkan talak tiga dalam satu kali ucapan.
\end{abstract}

Kata Kunci : Perbedaan talak, Hukum Islam

\section{PENDAHULUAN}

Dalam Islam, salah satu bentuk pemutusan hubungan ikatan perkawinan karena sebab-sebab tertentu yang tidak memungkinkan lagi bagi suami istri meneruskan hidup berumah tangga disebut thalaq/tala.

Arti talak itu sendiri menurut Kompilasi hukum Islam (KHI) adalah ikrar suami dihadapan Pengadilan agama yang menjadi salah satu sebab putusnya perkawinan.

Mengenai talak diatur lebih lanjut dalam Pasal 129, Pasal 130, dan Pasal 131 KHI. Pasal 129 KHI berbunyi :

"Seorang suami yang akan menjatuhkan talak kepada istrinya mengajukan permohonan baik lisan maupun tertulis kepada Pengadilan Agama yang mewilayahi tempat tinggal istri disertai dengan alasan serta meminta agar diadakan siding untuk keperluan itu" 
JUSTISI | 2019

Jadi talak yang diakui secara hukum Negara adalah yang dilakukan atau diucapkan oleh suami di Pengadilan Agama. Sedangkan, mengenai talak yang dilakukan atau diucapkan diluar Pengadilan hanya sah menurut hukum agama saja, tetapi tidak sah menurut hukum yang berlaku di Negara Indonesia karena tidak dilakukan di Pengadilan Agama dan ikatan perkawinan antara suami istri tersebut belum putus secara hukum. Berdasarkan uraian tersebut diatas maka dapat dirumuskan masalah pokok sebagai berikut : (a) Bagaimanakah perbedaan antara talak satu, dua dan tiga? (b) Dalam menjatuhkan talak, haruskah berurutan?

\section{PEMBAHASAN}

\section{Pengertian Talak}

Talak adalah ucapan suami yang ditujukan kepada istri yang mengakibatkan putusnya hubungan suami istri. Talak diucapkan oleh suami kepada istri secara disengaja baik dengan sighat langsung ataupun dengan sindiran.

\section{Perbedaan Talak Satu, Dua dan tiga}

Seorang suami dapat menjatuhkan talak kepada istri sebanyak tiga kali selama hukumnya tidak haram. Berdasarkan pendapat ulama maka talak dibagi menjadi beberapa kategori yakni : (a) Talak Raj'I : talak raj'I adalah talak yang dijatuhkan oleh suami dan setelah dijatuhkan talak, suami masih memiliki hak untuk rujuk dengan istrinya salama dalam masa iddah, talak yang pertama disebut talak satu sedangkan talak yang diucapkan kedua kalinya disebut talak dua. Talak satu dan talak dua dapat digolongkan dalam talak raj'I karena baik setelah talak satu dan dua suami masih bisa merujuk istrinya selama masa iddah. Rajuk yang dimaksud adalah suami dapat kembali tinggal dan menggauli istrinya tanpa harus melakukan akad yang baru dan tanpa menunggu persetujuan sang isteri. Rujuk dapat dilakukan hanya dengan mengucapkan kata "saya kembali padamu" dihadapan dua orang saksi laki-laki yang adil. (b) Talak ba'in : talak ba'in yang didalamnya termasuk didalam talak tiga dibagi menjadi dua yakni pertama Talak ba'inunah shugra (perpisahan yang kecil). Talak ba'inunah shugra atau perpisahan kecil adalah talak yang dijatuhkan suami kepada istri dan setelah dijatuhkannya talak tersebut suami tidak lagi memiliki peluang untuk 
JUSTISI | 2019

rujuk dengan istrinya. Apabila suami ingin kembali kepada istrinya maka suami harus meminta persetujuan dari sang istri dan harus diawalidengan akad yang baru tetapi tidak harus dinikahi oleh laki-laki lain terlebih dahulu.

Talak ini terjadi secara otomatis apabila setelah masa iddah sang istri selesai setelah jatuhnya talak raj'I suami belum melakukan atau rujuk kembali. Hal ini juga berlaku pada suami yang mentalak istrinya yang belum pernah digauli sebelumnya.

Kedua talak ba'inunah kubra (perpisahan yang besar). Talak ba'inunah kubra adalah talak yang dijatuhkan suami kepada istri dan setelah itu suami tidak bisa rujuk atau menikah kembali dengan istri sebelum bekas istrinya menikah dengan laki-laki lain dan kemudian laki-laki itu menceraikannya atau meninggal dunia.

Talak ba'inunah kubra juga diketahui sebagai talak tiga. Hal ini dapat digambarkan seperti jika suami mentalak istrinya kemudian rujuk untuk pertama kali, kemudian suami kembali menalak istrinya untuk kedua kali atau talak dua setelah itu suami kembali rujuk. Apabila setelah rujuk kedua kalinya suami masih menjatuhkan talak kembali atau talak ketiga maka haram baginya untuk kembali merujuk atau menikahi istrinya. Suami hanya dapat menikah kembali pada istrinya apabila sang istri telah menikah kembali dan bercerai dengan suaminya.

Demikian pengertian talak satu, dua dan tiga serta perbedaanya. Dapat disimpulkan bahwa perbedaan talak satu, dua dan tiga adalah akibat yang ditimbulkannya. Pada talak satu dan dua suami masuh bisa merujuk istri tanpa harus mengucapkan akad yang baru dan dilakukan dalam masa iddah sang istri, sementara talak tiga suami tidak dapat rujuk kembali kepada istri sebelum sang istri menikah dengan laki-laki lain kemudian bercerai atau suami yang baru meninggal dunia.

\section{Dalam menjatuhkan talak haruskah berurutan}

Apabila seorang istri dijatuhkan talak satu atau dua oleh suaminya, maka suami istri tersebut diperintahkan untuk tetap tinggal satu atap. Demikianlah ajaran Islam, karena dengan demikian suami diharapkan bisa menimbang kembali dengan melihat istrinya yang tetap di rumah dan mengurus rumahnya. Demikian juga istri 
JUSTISI | 2019

diharapkan mau ber-islah kerena melihat suami tetap member nafkah dan tempat tinggal.

Dalam menjatuhkan talak suami tidak boleh langsung menjatuhkan talak tiga kepada istri, ini sesuai dengan ayat dalam al quran Surat Al Baqarah ayat 229 "Talak (yang dapat dirujuk itu) dua kali. Banyak ulama berpendapat bahwa talak tiga hanya bisa dilakukan setelah dua kali talak dan dua kali rujuk.

Meski demikian, ada yang berpendapat boleh dilakukan talak langsung tiga merujuk pada hadist :

"Di masa Rasulullah SAW, Abu bakr, lalu dua tahun di masa umar muncul ucapan talak tiga dalam sekali ucap. Umar pun berkata, "Manusia sekarang ini sungguh tergesah-gesah dalam mengucapkan talak tidak sesuai dengan aturan Islam yang dulu pernah berlaku, yaitu talak itu masih ada kesempatan untuk rujuk. Kerena ketergesa-gesaan ini, aku berharap bisa mensahkan talak tiga sekali ucap". Akhirnya Umar pun mensahkan talak tiga sekali ucap dianggap telah jatuh tiga kali talak." (HR.Muslim no 1472)"

Merujuk pada hadist diatas, boleh saja seorang suami langsung menjatuhkan talak tiga sekaligus. Namun kata Umar bahwa perbuatan langsung talak tiga adalah perbuatan tergesa-gesa. Dari pembahasan diatas dapat disimpulkan bahwa dalam menjatuhkan talak haruslah berurutan dan tidak boleh dalam sekali ucapan.

\section{SIMPULAN}

1. Dari uraian panjang yang telah dijelaskan sebelumnya maka kita dapat mengetahui perbedaan talak satu, dua dan tiga adalah akibat yang ditimbulkannya. Pada talak satu dan dua suami masuh bisa merujuk istri tanpa harus mengucapkan akad yang baru dan dilakukan dalam masa iddah sang istri, sementara talak tiga suami tidak dapat rujuk kembali kepada istri sebelum sang istri menikah dengan lakilaki lain kemudian bercerai atau suami yang baru meninggal dunia.

2. Dalam menjatuhkan talak kepada istri, sang suami tidak boleh menjatuhkan talak sekaligus tiga kepada istri dalam satu kali ucapan meskipun ada hadist yang 
membolehkam hal tersebut namun sebaiknya tidak dilakukan karena termasuk perbuatan yang tergesa-gesa.

\section{SARAN}

1. Perlu adanya sosialisasi kepada masyarakat mengenai syarat dan perbedaan talak itu sendiri agar masyarakat terhindar dari perbuatan yang sangat dibenci oleh Allah walaupun itu halal yaitu perceraian.

2. Dalam menjatuhkan talak sebaiknya suami tidak melakukannya dalam keadaan tergesa-gesa atau dalam keadaan emosi kepada istri. Kalaupun harus menjatuhkan talak kepada istri haruslah berurutan tidak boleh diucapkan tiga talak dalam sekali ucapan.

\section{DAFTAR PUSTAKA}

Al Quranul Karim

Saebani, Beni Ahmad, Figh Munakahat, Cv.Pustaka Setia 2001 :Bandung

Sayuti Thalib, 1986. Hukum Kekeluargaan Indonesia, UI-Press: Jakarta

Sukandarrumidi, Metodologi Penelitian Petunjuk Peraktis Untuk Peneliti Pemula, Cetakan III, Yogyakarta : Gadjah Mada University Press, 2006. 